\title{
Effect of thione-thiol tautomerism on the inhibition of lactoperoxidase by anti-thyroid drugs and their analogues
}

\author{
P N JAYARAM, GOURIPRASANNA ROY and GOVINDASAMY MUGESH* \\ Department of Inorganic and Physical Chemistry, Indian Institute of Science, Bangalore 560012 \\ e-mail: mugesh $a$ ipc.iisc.ernet.in
}

\begin{abstract}
The keto-enol type tautomerism in anti-thyroid drugs and their selenium analogues are described. The commonly used anti-thyroid drug methimazole exists predominantly in its thione form, whereas its selenium analogue exists in a zwitterionic form. To understand the effect of thione/thiol and selone/selenol tautomerism on the inhibition of peroxidase-catalysed reactions, we have synthesized some thiones and selones in which the formation of thiol/selenol forms are blocked by different substituents. These compounds were synthesized by a carbene route utilizing an imidazolium salt. The crystal structures of these compounds reveal that the $\mathrm{C}=$ Se bonds in the selones are more polarized than the $\mathrm{C}=\mathrm{S}$ bonds in the corresponding thiones. The structures of selones were studied in solution by NMR spectroscopy and the ${ }^{77}$ Se NMR chemical shifts for the selones show large upfield shifts in the signals, confirming their zwitterionic structures in solution. The inhibition of lactoperoxidase by the synthetic thiones indicates that the presence of a free N-H moiety is essential for an efficient inhibition. In contrast, such moiety is not required for an inhibition by the selenium compounds.
\end{abstract}

Keywords. Anti-thyroid drugs; bioinorganic chemistry; enzyme inhibition; lactoperoxidase; methimazole.

\section{Introduction}

The heme peroxidase superfamily of 'mammalian peroxidases' include lactoperoxidase (LPO), myeloperoxidase (MPO), eosinophil peroxidase (EPO) and thyroid peroxidase (TPO), which catalyse several important biological reactions. ${ }^{1}$ Thyroid peroxidase (TPO), in particular, involves in the biosynthesis of the thyroid hormone, thyroxine (T4). The synthetic routes for thyroxine generation in thyroid gland catalysed by TPO involve two distinct reactions: iodination of tyrosyl residues in tyroglobulin $(\mathrm{Tg})$ and phenolic coupling of the resulting iodinated tyrosyl residues. ${ }^{2}$ The first step in the thyroid hormone biosynthesis is the oxidation of the iron center in the native enzyme by hydrogen peroxide to form compound I that exist in two different forms: an oxoferryl protein radical and an oxoferryl porphyrin pi-cation radical. In the presence of reducing agents such as iodide and thyroglobulin, iodide is rapidly oxidized by $\pi$-cation radical to an iodinating species that is involved in the iodination of the tyrosyl residues on $\mathrm{Tg}$. The coupling reaction occurs simultaneously with iodination by the $\pi$-cation radical (figure 1).

*For correspondence
The prohormone $\mathbf{T 4}$, produced by the TPO/ $\mathrm{H}_{2} \mathrm{O}_{2} / \mathrm{I}^{-}$system, is then converted to its biologically active form $\mathbf{T} 3$ by an outer ring de-iodination pathway. This particular reaction is catalysed by an iodothyronine deiodinase (ID-I), which is present in highest amounts in liver, kidney, thyroid and pituitary. ${ }^{3}$ The thyroid gland also produces an inactive metabolite rT3 by an inner ring deiodination pathway. The triiodo derivatives T3 and rT3 are further

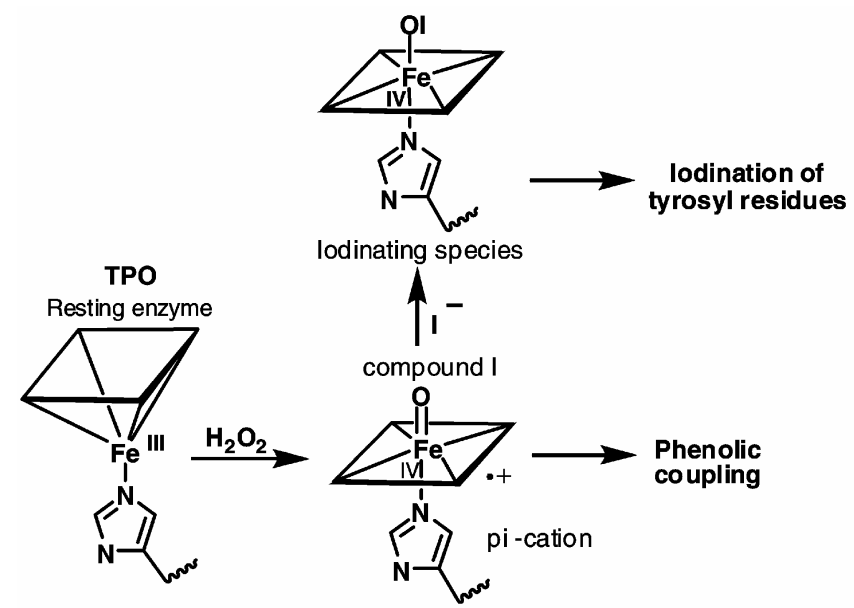

Figure 1. Synthesis of thyroid hormones by hemecontaining thyroid peroxidase (TPO). 
metabolized by inner ring and outer ring de-iodination, respectively, by ID-I, and two other iodothyronine deiodinases called ID-II and ID-III to produce the inactive metaboilite T2 (3,3'-T2, 3,5-T2 and $3^{\prime}, 5^{\prime}-$ T2). The outer ring 5'-de-iodination catalysed by the ID-I enzyme is considered to be the first step in thyroid hormone action, because this is the only deiodination pathway that leads to the formation of an active thyroid hormone. ${ }^{3}$

Although the iodination and de-iodination reactions are essential for the function of thyroid gland, the activation of thyroid stimulating hormone (TSH) receptor by auto-antibodies leads to an overproduction of thyroid hormones. As these antibodies are not under pituitary feedback control system, there is no negative influence on the thyroid activity and, therefore, the uncontrolled production of thyroid hormones leads to a condition called 'hyperthyroidism' ${ }^{3}$ The overproduction of T4 and T3 can be controlled by blocking the thyroid hormone biosynthesis or reducing the conversion of $\mathbf{T 4}$ to $\mathbf{T 3}$. The thiourea drugs such as methimazole (1, MMI), 6-npropyl-2-thiouracil (3, PTU), and 6-methyl-2-thiouracil (5, MTU) are generally employed for reducing the thyroid hormone level (figure 2). Although the precise mechanism of their action is not known, these compounds have been shown to reduce the formation of thyroxine by inhibiting the TPO enzyme. ${ }^{4}$ MMI has been found to be particularly effective and this imidazole-based compound normally leads to an irreversible inhibition of the enzyme. The thioureabased compounds PTU (3) and MTU (5) also inhibit the TPO activity, but their action on the enzyme is not completely irreversible.

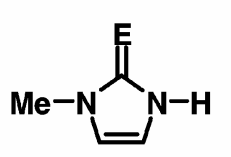

1, $E=S(M M I)$

2, $E=\operatorname{Se}($ MSel)

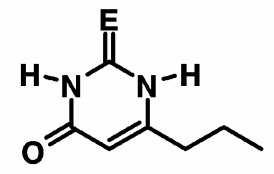

3, $E=S(P T U)$

4, $E=S e(P S e U)$

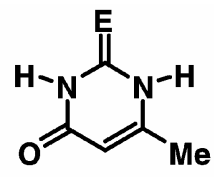

$5, E=S(M T U)$

6, $\mathrm{E}=\mathrm{Se}(\mathrm{MSeU})$
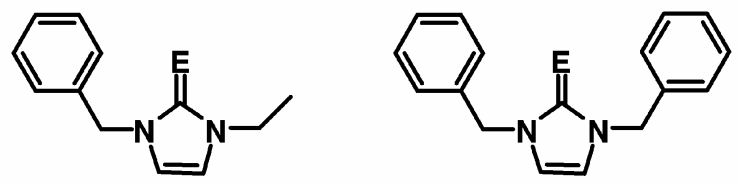

7, $E=S ; 8, E=S e$

9, $E=S ; 10, E=S e$

Figure 2. Chemical structures of some anti-thyroid drugs and their analogues.
In recent years, the selenium analogues of MMI (2, MSeI), PTU (4, PSeU) and MTU (6, MSeU) attracted considerable attention. ${ }^{5,6}$ The selenium analogues may exhibit much higher inhibitory activity towards TPO as compared with their sulfur analogues due to their high nucleophilic character. In addition to their inhibitory action, the selenium analogues may have significant effect on the hydrogen peroxide and other reactive oxygen species. The degradation of the intracellular hydrogen peroxide by the selenium analogues of anti-thyroid drugs may be beneficial to the thyroid gland as these compounds may act as antioxidants and protect thyroid cells from oxidative damage. In this regard, our group is working on the mechanism of the inhibition of peroxidase-catalysed oxidation and iodination reactions by anti-thyroid drugs and their selenium analogues. Recently, we have shown that the selenium analogue of MMI (i.e. MSeI) is unstable and this compound oxidizes spontaneously to produce the corresponding diselenide. ${ }^{6}$ In this paper, we describe the importance of the thione moiety in anti-thyroid agents and the effect of thiol/thione and selenol/ selone tautomerism on peroxidase-catalysed oxidation reactions.

\section{Experimental}

\subsection{General procedure}

Lactoperoxidase from bovine milk and ABTS (2,2'azino-bis 3-ethylbensthiazoline sulfonic acid) were purchased from Fluka Chemical Co. $n$-Butyllithium was purchased from Acros Chemical Co. (Belgium). Sodium borohydride $\left(\mathrm{NaBH}_{4}\right)$, benzyl chloride, suphfur and selenium powder were obtained from Aldrich. The anti-thyroid drugs 2-mercapto-1-methylimidazole 1; 6- $n$-propyl-2-thiouracil 3; 6-methyl-2uracil 5 were obtained from TCI (Tokyo Kasei, Japan) company. All other chemicals were of the highest purity available. All experiments were carried out under dry and oxygen free argon/nitrogen using standard Schlenk techniques for the synthesis. Due to unpleasant odors of several of the reaction mixtures involved, most manipulations were carried out in a well-ventilated fume hood. Melting points were determined in open tubes on a Buchi melting point B-540 apparatus and are uncorrected. Mass spectral (MS) studies were carried out on a Q-TOF Micro mass spectrometer with electrospray ionization MS mode analysis. In the case of isotopic patterns, the 
value given is for the most intense peak. Elemental analyses were performed on a ThermoFinigan FLASH EA 1112 CHNS analyser. Liquid state NMR spectra were recorded in $\mathrm{CDCl}_{3}$ as a solvent. ${ }^{1} \mathrm{H}(400 \mathrm{MHz})$, ${ }^{13} \mathrm{C}(100 \mathrm{MHz})$ and ${ }^{77} \mathrm{Se}(76 \cdot 3 \mathrm{MHz})$ NMR spectra were obtained on a Bruker Avance 400 NMR Spectrometer using the solvent as an internal standard for ${ }^{1} \mathrm{H}$ and ${ }^{13} \mathrm{C}$. Chemical shifts $\left({ }^{1} \mathrm{H},{ }^{13} \mathrm{C}\right)$ are cited with respect to tetramethylsilane (TMS). The ${ }^{77} \mathrm{Se}$ NMR spectra were recorded using diphenyl diselenide as an external standard. The ${ }^{77} \mathrm{Se}$ NMR chemical shifts are reported relative to dimethyl selenide $(0 \mathrm{ppm})$ by assuming that the resonance of the standard is at $461.0 \mathrm{ppm}$. In most of the cases, the ${ }^{77} \mathrm{Se}$ NMR experiments were run overnight to obtain good quality spectra. Thin-layer chromatography analyses were carried out on pre-coated silica gel plates (Merck) and spots were visualized by UV irradiation. Column chromatography was performed on glass columns loaded with silica gel or on automated flash chromatography system (Biotage) by using pre-loaded silica cartridges. High performance liquid chromatography (HPLC) experiments were carried out on a Waters Alliance System (Milford, MA) consisting of a 2690 separation module, a 2690 photodiode-array detector and a fraction collector. The assays were performed in $1.8 \mathrm{~mL}$ sample vials and a built-in autosampler was used for sample injection. The Alliance HPLC System was controlled with EMPOWER software (Waters Corporation, Milford, MA).

2.1a Synthesis of 1-benzyl-1H-imidazole: A mixture of imidazole ( $3.26 \mathrm{~g}, 0.048 \mathrm{~mol}$ ), benzyl chloride $(6.08 \mathrm{~g}, 0.048 \mathrm{~mol})$ and four equivalents of sodium hydride $(60 \% ; 7.68 \mathrm{~g}, 0.19 \mathrm{~mol})$ was refluxed overnight in dry THF $(50 \mathrm{~mL})$ under nitrogen atmosphere. The solvent was removed completely under vacuum. The resulting residue was treated with water $(30 \mathrm{~mL})$ and dichloromethane $(30 \mathrm{~mL})$, the organic layer was washed two more times with water to remove the excess sodium hydride, and then separated and dried it over anhydrous sodium sulfate. The solvent was removed completely under vacuum to give a pale yellow solid. This was washed with petroleum ether to remove the non-polar impurities, the residue was dried under vacuum to afford a pale yellow solid. Yield: $6.21 \mathrm{~g}, 82 \% \cdot \mathrm{m} . \mathrm{p} .71-73^{\circ} \mathrm{C} .{ }^{1} \mathrm{H}$ NMR $\left(\mathrm{CDCl}_{3}, \mathrm{ppm}\right): \delta=5.12\left(s, 2 \mathrm{H}\right.$ of $\left.\mathrm{PhCH}_{2}\right), 6.90(s$, $1 \mathrm{H}, \mathrm{NCH}$ of imidazole ring), $7.09(s, \mathrm{IH}, \mathrm{NCH}$ of imidazole ring), 7.27 ( $m, 5 \mathrm{H}, \mathrm{CH}$ of benzene ring), $7.56(s, 1 \mathrm{H}, \mathrm{NCH}) ;{ }^{13} \mathrm{C}$ NMR $\left(\mathrm{CDCl}_{3}, \mathrm{ppm}\right)$ : $\delta=50 \cdot 9\left(\mathrm{CH}_{2} \mathrm{Ph}\right), 119 \cdot 4,136 \cdot 2$ (C of imidazole $)$, $127 \cdot 3,128 \cdot 3,129 \cdot 0,129 \cdot 9$, (C of benzene ring), 137.4 (NCN of imidazole ring).

2.1b Synthesis of-1-benzyl-3-ethyl-1H-imidazole2(3H)-thione (7): 1-Benzylimidazole $(0.2 \mathrm{~g}, 1.26 \mathrm{mmol})$ was dissolved in $10 \mathrm{~mL}$ of ethyl acetate in a $50 \mathrm{~mL}$ two-neck round bottom flask fitted with a reflux condenser. To the solution, ethyl bromide $(0.1 \mathrm{~mL}$, $1.26 \mathrm{mmol}$ ) was added drop-wise. This reaction mixture was refluxed for $24 \mathrm{~h}$, and then the solvent was removed under vacuum to get a pale yellow solid. The solid obtained in the first step was taken in a $50 \mathrm{~mL}$ two-neck round bottom flask fitted with a reflux condenser and was added dry methanol $(25 \mathrm{~mL})$. The resulting solution was treated with sulfur powder $(0.04 \mathrm{~g}, 1.26 \mathrm{mmol})$ and anhydrous potassium carbonate $(0.16 \mathrm{~g}, 1.15 \mathrm{mmol})$. The reaction mixture was heated to reflux for $24 \mathrm{~h}$. The solution was then filtered through a pad of Celite and washed two times with dry methanol. The small impurities in the sample can be removed by column chromatography (silica gel) by using $1: 1$ ethyl acetate: petroleum ether. Yield: $0 \cdot 13 \mathrm{~g}(47 \%)$. m.p. $87-89^{\circ} \mathrm{C}$. ${ }^{1} \mathrm{H}$ $\operatorname{NMR}\left(\mathrm{CDCl}_{3}, \mathrm{ppm}\right): \delta=1.39\left(t, 3 \mathrm{H}, J_{\mathrm{H}-\mathrm{H}}=7.2 \mathrm{~Hz}\right.$, of $\left.\mathrm{NCH}_{2} \mathrm{CH}_{3}\right), 4 \cdot 13\left(q, 2 \mathrm{H}, J_{\mathrm{H}-\mathrm{H}}=7 \cdot 2 \mathrm{~Hz}\right.$, of $\left.\mathrm{NCH}_{2}\right)$, $5.26\left(s, 2 \mathrm{H}, \mathrm{NCH}_{2}\right), 6.56\left(d, \mathrm{IH}, J_{\mathrm{H}-\mathrm{H}}=2 \mathrm{~Hz}, \mathrm{C}-\mathrm{H}\right.$ of imidazole ring), $6.68\left(d, \mathrm{IH}, \mathrm{J}_{\mathrm{H}-\mathrm{H}}=2.4 \mathrm{~Hz}, \mathrm{C}-\mathrm{H}\right.$ of imidazole ring $), 7.33(\mathrm{~m}, 5 \mathrm{H}, \mathrm{CH}$ of benzene ring); ${ }^{13} \mathrm{C}$ NMR $\left(\mathrm{CDCl}_{3}, \mathrm{ppm}\right): \delta=13.2\left(\mathrm{CH}_{3}\right), 41 \cdot 9$ $\left(\mathrm{CH}_{2}\right.$ of ethyl group), $50 \cdot 1\left(\mathrm{CH}_{2} \mathrm{Ph}\right), 115 \cdot 1,115 \cdot 5$ ( $\mathrm{CH}$ of imidazole ring), 127.1, 127.3, 127.8, 134.8 ( $\mathrm{CH}$ of benzene ring), $161 \cdot 1 \quad(\mathrm{C}=\mathrm{S}$ of imidazole ring).

2.1c Synthesis of-1-benzyl-3-ethyl-1H-imidazole2(3H)-selone (8): 1-Benzylimidazole (0.2 g, $1.26 \mathrm{mmol})$ was dissolved in $10 \mathrm{~mL}$ of ethyl acetate in a $50 \mathrm{~mL}$ two-neck round bottom flask fitted with a reflux condenser. To the solution, ethyl bromide $(0.1 \mathrm{~mL}$, $1.26 \mathrm{mmol}$ ) was added drop-wise. This solution was refluxed for $24 \mathrm{~h}$, and then the solvent was removed under vacuum to give a pale yellow solid. The solid obtained in the first step was taken in a $50 \mathrm{~mL}$ twoneck round bottom flask fitted with a reflux condenser and was added dry methanol $(25 \mathrm{~mL})$. The resulting solution was treated with activated selenium powder $(0.1 \mathrm{~g}, 1.26 \mathrm{mmol})$ and anhydrous potassium carbonate $(0.16 \mathrm{~g}, 1.15 \mathrm{mmol})$. The reaction mixture was heated to reflux for $24 \mathrm{~h}$. The solution was then filtered through a pad of celite to remove 
the unreacted selenium and washed with methanol. The small impurities in the sample can be removed by column chromatography (silica gel) by using $1: 1$ ethyl acetate: petroleum ether. Yield: $0.16 \mathrm{~g}$ (47\%). m.p. $92-94{ }^{\circ} \mathrm{C} .{ }^{1} \mathrm{H}$ NMR $\left(\mathrm{CDCl}_{3}, \mathrm{ppm}\right): \delta=1.41(t$, $3 \mathrm{H}, J_{\mathrm{H}-\mathrm{H}}=7 \cdot 2 \mathrm{~Hz}$, of $\left.\mathrm{NCH}_{2} \mathrm{CH}_{3}\right), 4.23\left(q, 2 \mathrm{H}, J_{\mathrm{H}-\mathrm{H}}=\right.$ $\left.7 \cdot 2 \mathrm{~Hz}, \mathrm{NCH}_{2}\right), 5 \cdot 36\left(s, 2 \mathrm{H}, \mathrm{NCH}_{2}\right), 6 \cdot 73\left(d, \mathrm{IH}, J_{\mathrm{H}-\mathrm{H}}=\right.$ $2 \mathrm{~Hz}, \mathrm{C}-\mathrm{H}$ of imidazole ring $), 6 \cdot 86\left(d, \mathrm{IH}, J_{\mathrm{H}-\mathrm{H}}=\right.$ $2.4 \mathrm{~Hz}, \mathrm{C}-\mathrm{H}$ of imidazole ring), $7.34(\mathrm{~m}, 5 \mathrm{H}, \mathrm{CH}$ of benzene ring); ${ }^{13} \mathrm{C}$ NMR $\left(\mathrm{CDCl}_{3}, \mathrm{ppm}\right): \delta=13.5$ $\left(\mathrm{CH}_{3}\right), 43.9\left(\mathrm{CH}_{2}\right.$ of ethyl group $), 51.9\left(\mathrm{CH}_{2} \mathrm{Ph}\right)$, 117.3, 117.7, ( $\mathrm{CH}$ of imidazole ring), 127.3, 127.4, $127.9,134.5$ ( $\mathrm{CH}$ of benzene ring), $154.5(\mathrm{C}=\mathrm{Se}$ of imidazole ring); ${ }^{77} \mathrm{Se} \mathrm{NMR}\left(\mathrm{CDCl}_{3}, \mathrm{ppm}\right): \delta=-9$; Elemental analysis: Anal. Calcd. for $\mathrm{C}_{12} \mathrm{H}_{14} \mathrm{~N}_{2} \mathrm{Se}$ : C, 54.34; H, 5.32; N, 10.56 Found: C, 54.49; H, 5.51; $\mathrm{N}, 10 \cdot 49$.

2.1d Synthesis of 1,3-dibenzyl-1H-imidazole-2(3H)thione (9): Benzyl chloride $(0.8 \mathrm{~mL}, 6.96 \mathrm{mmol})$ was added to a two-neck flask containing sodium iodide $(1.04 \mathrm{~g}, 6.96 \mathrm{mmol})$ and 1-benzylimidazole $(1.0 \mathrm{~g}, 6.33 \mathrm{mmol})$ in $20 \mathrm{~mL}$ acetone. The reaction mixture was stirred for $6 \mathrm{~h}$ at room temperature. The solvent was removed under vacuum and the resulting residue was treated with dichloromethane. The mixture was stirred for $5 \mathrm{~min}$ and the precipitated sodium chloride was removed by filtration. The solvent dichloromethane was evaporated under reduced pressure to yield a yellow solid, which was used for the next step without any further purification. The yellow solid obtained in the first step was taken in a $100 \mathrm{~mL}$ two-neck round bottom flask fitted with a reflux condenser and was added dry methanol $(30 \mathrm{~mL})$. The resulting slurry was treated with sulfur powder $(0.2 \mathrm{~g}, 6.33 \mathrm{mmol})$ and anhydrous potassium carbonate $(0.8 \mathrm{~g}, 5.80 \mathrm{mmol})$. The reaction mixture was heated to reflux for $8 \mathrm{~h}$. The solution was then filtered in hot condition through a pad of Celite and washed two times with dry methanol. The desired compound was obtained as a white crystalline solid. The small impurities in the sample can be removed by column chromatography (silica gel) using $1: 5$ ethyl acetate: petroleum ether. Yield: $0.80 \mathrm{~g} \mathrm{(45 \% ).}$ m.p. $103-105^{\circ} \mathrm{C} .{ }^{1} \mathrm{H}$ NMR $\left(\mathrm{CDCl}_{3}, \mathrm{ppm}\right): \delta=5 \cdot 30$ $\left(s, 4 \mathrm{H}\right.$ of $\left.\mathrm{NCH}_{2} \mathrm{Ph}\right), 6.54(s, 2 \mathrm{H}, \mathrm{NCH}), 7.33(m$, $10 \mathrm{H}, \mathrm{CH}$ of benzene ring); ${ }^{13} \mathrm{C} \mathrm{NMR}\left(\mathrm{CDCl}_{3}, \mathrm{ppm}\right)$ : $\delta=51.4\left(\mathrm{NCH}_{2} \mathrm{Ph}\right), 116.8(\mathrm{CH}$ of imidazole ring $)$, $128.2,128.4,128.9,135.9$ ( $\mathrm{CH}$ of benzene ring), 163.2 ( $\mathrm{C}=\mathrm{S}$ of imidazole ring); HRMS $\mathrm{m} / z$ (TOF) calcd. for $\mathrm{C}_{17} \mathrm{H}_{16} \mathrm{~N}_{2} \mathrm{~S}[\mathrm{M}+\mathrm{Na}]^{+}$303.0932, found
303.0930; Elemental analysis: Anal. calcd. for $\mathrm{C}_{17} \mathrm{H}_{16} \mathrm{~N}_{2} \mathrm{~S}$ : C, 72.82; H, 5.75; N, 9.99 Found: C, $72 \cdot 74 ; \mathrm{H}, 6 \cdot 0 ; \mathrm{N}, 10 \cdot 09$.

2.1e Synthesis of 1,3-dibenzyl-1H-imidazole-2(3H)selone (10): Benzyl chloride $(0.8 \mathrm{~mL}, 6.96 \mathrm{mmol})$ was added to a two-neck flask containing sodium iodide $(1.04 \mathrm{~g}, 6.96 \mathrm{mmol})$ and 1-benzylimidazole $(1.0 \mathrm{~g}, 6.33 \mathrm{mmol})$ in $20 \mathrm{~mL}$ acetone. The reaction mixture was stirred for $6 \mathrm{~h}$ at room temperature. The solvent was removed under vacuum and the resulting residue was treated with dichloromethane. The mixture was stirred for $5 \mathrm{~min}$ and the precipitated sodium chloride was removed by filtration. The solvent dichloromethane was evaporated under reduced pressure to yield a yellow solid, which was used for the next step without any further purification. The yellow solid obtained in the first step was taken in a $100 \mathrm{~mL}$ two-neck round bottom flask fitted with a reflux condenser and was added dry methanol $(30 \mathrm{~mL})$. The resulting slurry was treated with activated selenium powder $(0.5 \mathrm{~g}, 6.33 \mathrm{mmol})$ and anhydrous potassium carbonate $(0.8 \mathrm{~g}, 5.80 \mathrm{mmol})$. The reaction mixture was heated to reflux for $8 \mathrm{~h}$. The solution was then filtered in hot condition through a pad of Celite and washed two times with dry methanol. The desired compound was obtained as a white crystalline solid. The small impurities in the sample can be removed by column chromatography (silica gel) by using 1:5 ethyl acetate: petroleum ether. Yield: $0.85 \mathrm{~g}(40 \%)$ m.p. $112-1144^{\circ} \mathrm{C} .{ }^{1} \mathrm{H}$ NMR $\left(\mathrm{CDCl}_{3}, \mathrm{ppm}\right): \delta=5.38\left(s, 4 \mathrm{H}\right.$ of $\left.\mathrm{NCH}_{2} \mathrm{Ph}\right)$, $6.87(s, 2 \mathrm{H}, \mathrm{NCH}), 7.33(\mathrm{~m}, 10 \mathrm{H}, \mathrm{CH}$ of benzene ring); ${ }^{13} \mathrm{C}$ NMR $\left(\mathrm{CDCl}_{3}, \mathrm{ppm}\right): \delta=53.4\left(\mathrm{NCH}_{2} \mathrm{Ph}\right)$, 118.9 ( $\mathrm{CH}$ of imidazole ring), 128.4, 128.5, 129.0, 135.5 ( $\mathrm{CH}$ of benzene ring), 157.1 ( $\mathrm{C}=\mathrm{Se}$ of imidazole ring); ${ }^{77} \mathrm{Se} \mathrm{NMR}\left(\mathrm{CDCl}_{3}, \mathrm{ppm}\right): \delta=0$. HRMS $m / z$ (TOF) calcd for $\mathrm{C}_{17} \mathrm{H}_{16} \mathrm{~N}_{2} \mathrm{Se}[\mathrm{M}+\mathrm{Na}]^{+} 351.0376$, found 351.0374; Elemental analysis: Anal. calcd. C, $62.39 ; \mathrm{H}, 4.93 ; \mathrm{N}, 8.56$ Found: C, 62.31; H, 4.85; N, 8.63 .

2.1f LPO-catalysed oxidation: The LPO inhibition experiments were performed in phosphate buffer $(\mathrm{pH} 7 \cdot 0)$ at $25^{\circ} \mathrm{C}$. The spectral measurements were carried out on a UV-Vis spectrophotometer and the assay of LPO enzyme activity was followed by catalysis of the oxidation of ABTS. The initial rate for the oxidation reaction was calculated by following UV absorption increase at $411 \mathrm{~nm}$. Enzyme activity after the addition of various inhibitors was expressed 
as the percentage of that observed in the absence of inhibitors. The peroxide concentration was always present in excess with respect to enzyme. The inhibition plots were obtained by using Origin 6.1 software and these plots were used for the calculation of the $\mathrm{IC}_{50}$ values. In a typical experiment, $100 \mathrm{mM}$ ABTS (used as diammonium salt) and $30 \mathrm{mM}$ hydrogen peroxide (from $30 \% \mathrm{w} / \mathrm{w}$ solution) solutions were freshly prepared in deionized water. Lactoperoxidase enzyme solution containing $0 \cdot 15-0.25$ unit $/ \mathrm{mL}$ was prepared in cold deionized water and used immediately for the assay. In a $1 \mathrm{~mL}$ reaction mixture, the final concentrations are $12.9 \mathrm{nM}$ LPO, $28.7 \mu \mathrm{M}$ $\mathrm{H}_{2} \mathrm{O}_{2}, 1.4 \mathrm{mM}$ ABTS and 1-200 mM inhibitor. For the compounds that are not soluble in buffer, a minimum amount of DMSO $(\sim 10 \mu \mathrm{L})$ and diluted with the test buffer. Likewise the control reactions were carried out with the same amount of DMSO.

2.1g Single crystal X-ray crystallography: X-ray crystallographic studies were carried out on a Bruker CCD diffractometer with graphite-monochromatized Mo-K $\alpha$ radiation $(\lambda=0.71073 \AA)$ controlled by a Pentium-based PC running on the SMART software package. (Bruker AXS: Madison, WI). Single crystals were mounted at room temperature on the ends of glass fibres and data were collected at room temperature. The structures were solved by direct methods and refined using the SHELXTL software package (Siemens Industrial Automation Inc.: Madison, WI) ${ }^{24}$ In general, all non-hydrogen atoms were refined anisotropically. Hydrogen atoms were assigned idealized locations. Empirical absorption corrections were applied to all structures using SADABS. (Siemens Industrial Automation Inc.: Madison, WI). ${ }^{25,26}$

\section{Results and discussion}

\subsection{Thiol/thione and selenol/selone tautomerism}

The keto-enol type tautomerism in the anti-thyroid drugs and their selenium analogues has been a focus of several investigations. ${ }^{7}$ It is known that the antithyroid agent MMI (1) exists almost exclusively as the thione tautomer, which is important for the inhibition of thyroid hormone synthesis. The other sulfur-containing drugs, PTU (4) and MTU (6) have also been shown to exist as the thione tautomers. ${ }^{7}$ The stability of the thione tautomer may prevent these compounds from being oxidized spontaneously to their corresponding disulfides, which may account for their high anti-thyroidal activity. Laurence et al have shown that the thione tautomer of MMI is responsible for its complexation with diiodine and the iodine complex of the thione tautomer $1 \mathbf{a}$ is favoured by $13.2 \mathrm{~kJ} \mathrm{~mol}^{-1}$ compared to that of the thiol tautomer 1b. ${ }^{7 \mathrm{~g}}$ Therefore, the facile oxidation of $\mathbf{2}$ to the corresponding diselenide requires the compound to be in its selenol form (2b) and not in the selone form (2a) (figure 3). Although compound 2 can exist in both selenol and selone forms in solution, the ${ }^{77} \mathrm{Se}$ NMR spectrum recorded immediately after the workup of the reaction showed a signal at $4 \mathrm{ppm}$, which cannot be ascribed to the true selone (2a) or undissociated selenol (2b) tautomer, but it can be ascribed to a species with more negative charge on selenium (2c). In the presence of air, this species slowly oxidizes to the corresponding diselenide, which shifts the equilibrium from a selone to a dissociated selenol, and this process continues until all the selone-selenolate mixture is converted to diselenide. ${ }^{6 \mathrm{~b}}$ In contrast, the sulfur analogue, which exists predominantly in its thione tautomer form (1a), was found to be stable under normal atmosphere.

The synthesis of the selenium analogue of methimazole (2, MSeI) was first described by Guziec et $a l .{ }^{5 \mathrm{~d}}$ In this case, the authors have mentioned that their initial attempts to synthesize MSeI by an alkylation-selenation sequence, commonly employed for the preparation of acyclic selenoureas, did not afford the desired selone. However, an alternative approach involving low temperature metallation of 1-methylimidazole, followed by selenium insertion afforded the desired compound in moderate yield. ${ }^{5 \mathrm{~d}}$ This methodology was recently employed by Parkin et al to synthesize 1-mesityl-1,3-dihydro-imidazole-2selone. ${ }^{8}$ It should be mentioned that the replacement of $\mathrm{N}-\mathrm{H}$ moiety in MMI with an $\mathrm{N}-\mathrm{Me}$ group has been shown to abolish the inhibitory activity of MMI. ${ }^{9}$ Therefore, it would be interesting to know whether the replacement of the free hydrogen atom

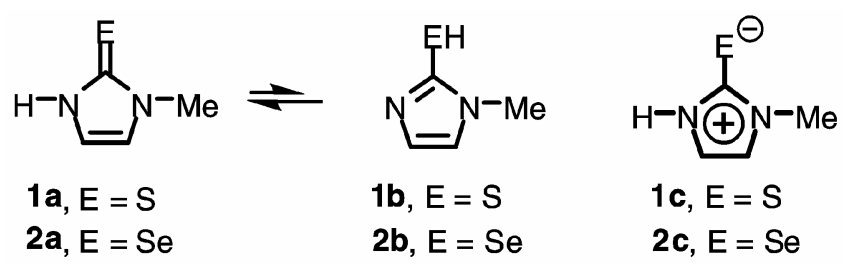

Figure 3. Tautomeric structures of MMI (1) and MSeI (2). ${ }^{6 \mathrm{~b}}$ 
in MMI and MSeI by other substituents would lead to inactive substances. In view of this, we have synthesized a variety of thiones and selones having different substituents on both the nitrogen atoms present in the 5-membered ring.

In the present study, the required starting material, 1-benzylimidazole, was synthesized conveniently from imidazole and benzylchloride. The treatment of imidazole with sodium hydride generated the corresponding anion, which upon reaction with benzyl chloride afforded the expected compound. The abstraction of the proton from the imidazole nitrogen was found to be a clean reaction due to the stabilization of the resulting anion by resonance contribution from the imidazole ring. The N,N-disubstituted derivatives (7-10) are not accessible via the low-temperature lithiation route. Therefore, the thiones $(7,9)$ and selones $(\mathbf{8}, \mathbf{1 0})$ were synthesized by a carbene route utilizing an imidazolium salt (scheme 1). The $\mathrm{N}, \mathrm{N}$-disubstituted derivatives were synthesized by treating 1-benzylimidazole with appropriate halides to produce the corresponding imidazolium salts, followed by reactions with elemental sulfur or selenium to afford the corresponding thiones or selones. In the first step of these reactions, the halides were added into the carbon-nitrogen double bond to give the corresponding N,N-substituted imidazolium salts. These salts were isolated and treated with a base (anhydrous potassium carbonate) and selenium or sulphur powder in dry methanol to give the corresponding selones and thiones. In these reactions, the deprotonation of imidazolium salts by the base leads to an in situ generation of reactive carbenes, which in turn react with elemental sulfur or selenium to afford the corresponding thiones or selones. These

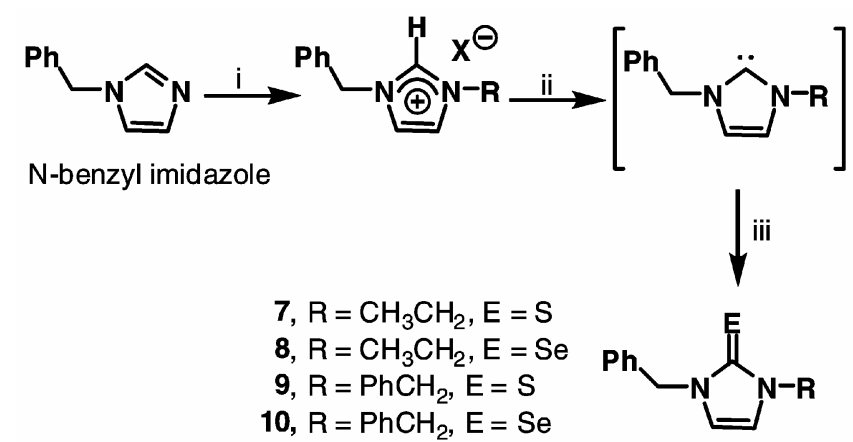

Scheme 1. Synthetic routes for compounds 7-10 via imidazolium salt/carbene. Reagents and conditions: (i) $\mathrm{RX}=\mathrm{CH}_{3} \mathrm{CH}_{2} \mathrm{Br}$ for compounds 7 and $\mathbf{8} ; \mathrm{RX}=\mathrm{PhCH}_{2} \mathrm{Cl}$ for compounds 9 and 10; (ii) dry methanol, $\mathrm{K}_{2} \mathrm{CO}_{3}$, reflux; (iii) S or Se powder. compounds are readily soluble in dichloromethane and are thus easily separated from salt-like components of the reaction mixture. In contrast to the selenium analogue of MMI, the selenium derivatives synthesized in the present study are found to be stable in the presence of air and we did not observe any oxidation leading to the formation of diselenides.

We have shown in our previous studies that the replacement of the N-H moiety in MSeI by an N-Me or $\mathrm{N}-\mathrm{Bz}$ group does not affect the nature of $\mathrm{C}-\mathrm{Se}$ bond or the electron density around the selenium center. ${ }^{6 \mathrm{~g}}$ The computational and ${ }^{77} \mathrm{Se}$ NMR spectroscopic studies on these compounds suggested that the molecules exist in their zwitterionic forms. The $\mathrm{X}$-ray structure of 1,3-dimethyl-2(3H)-imidazolethione (figure $4, \mathrm{R}=\mathrm{Me}$ ) was first reported by Ansel et $a l^{10}$ and based on the $\mathrm{C}-\mathrm{N}$ and $\mathrm{C}-\mathrm{C}$ bond lengths [C(thionyl)-N: 1.350 $\AA$; $\mathrm{C}$ (ethylenic)-N: $1.41 \AA$ and $\mathrm{C}=\mathrm{C}: 1.31 \AA]$ in the imidazole ring, they have proposed that the electronic structure of this compound would best be represented by a resonance hybrid of structures I and IV (figure 4). Tomlin et $a l^{11}$ on the other hand, re-evaluated the crystal structure of the same compound and proposed a more delocalized zwitterionic structure $\mathbf{V}$ (figure 4). We have shown in our previous studies that the replacement of sulfur with selenium leads to an elongation of the $\mathrm{C}-\mathrm{E}(\mathrm{E}=\mathrm{S}$ or $\mathrm{Se})$ bond and generation of a more delocalized structure. ${ }^{6 b, g}$ The crystal structure of 2 clearly showed that the two $\mathrm{C}-\mathrm{N}$ bond lengths are almost identical (N1-C1: 1.350; N2-C1: 1.346). ${ }^{6 \mathrm{~g}}$ Therefore, the N,N-disubstituted thiones and selones that we synthesized in the present work can be considered as zwitterions having large negative charge on selenium and delocalized positive charge in the 5 -membered ring.

The crystal structures of compounds 7, 9 and $\mathbf{1 0}$ (figure 5, table 1) reveal that these compounds do not have a true $\mathrm{C}=\mathrm{S}$ or $\mathrm{C}=\mathrm{Se}$ double bond. The $\mathrm{C}-\mathrm{S}$ bond lengths in the thiones $(7,9)$ are found to be in the range of 1.674 to $1.683 \AA$, indicating much shorter bond lengths as compared with a $\mathrm{C}-\mathrm{S}$ single bond (1.81 $\AA$ ), but longer bond lengths when compared with a $\mathrm{C}=\mathrm{S}$ double bond $(1.61 \AA){ }^{12}$ This suggests that the $\mathrm{C}-\mathrm{S}$ bonds in the thiones may be treated as partial double bonds. Similarly, the $\mathrm{C}-\mathrm{Se}$ bond in $\mathbf{1 0}$ is found to be much weaker than a typical $\mathrm{C}-\mathrm{Se}$ double bond and slightly stronger than a $\mathrm{C}-\mathrm{Se}$ single bond. The shortening of the adjacent $\mathrm{C}-\mathrm{N}$ bonds, a considerable elongation in the olefinic double bond $(\mathrm{C}=\mathrm{C}$ bond $)$ from a true $\mathrm{C}-\mathrm{C}$ double bond and a sig- 

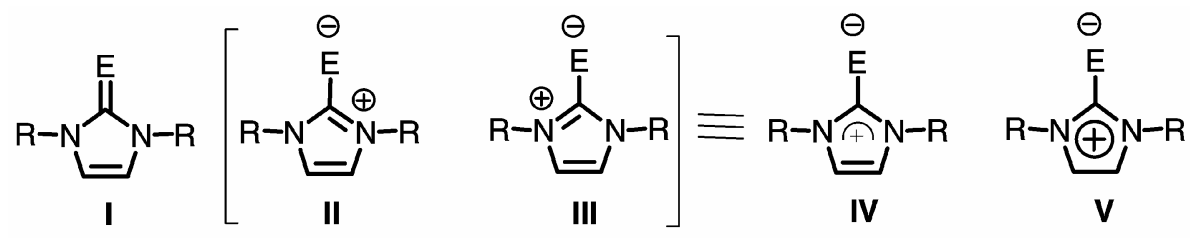

Figure 4. Possible tautomeric structures of $\mathrm{N}-\mathrm{N}$-disubstituted thiones $(\mathrm{E}=\mathrm{S})$ and selones $(\mathrm{E}=\mathrm{Se})$.

Table 1. Crystallographic data for compounds 7, 9 and $\mathbf{1 0 .}$

\begin{tabular}{llll}
\hline & \multicolumn{1}{c}{ Compd 7} & \multicolumn{1}{c}{ Compd 9 } & \multicolumn{1}{c}{ Compd 10 } \\
\hline Formula & $\mathrm{C}_{12} \mathrm{H}_{14} \mathrm{~N}_{2} \mathrm{~S}$ & $\mathrm{C}_{17} \mathrm{H}_{16} \mathrm{~N}_{2} \mathrm{~S}$ & $\mathrm{C}_{17} \mathrm{H}_{16} \mathrm{~N}_{2} \mathrm{Se}$ \\
$F_{w}$ & $218 \cdot 3$ & $276 \cdot 4$ & $326 \cdot 3$ \\
Crystal system & Orthorhombic & Monoclinic & Monoclinic \\
Space group & $P 222$ & $P 2(1) / n$ & $P 21$ \\
$a(\AA)$ & $6 \cdot 7558(11)$ & $7 \cdot 9600(11)$ & $7 \cdot 4223(8)$ \\
$b(\AA)$ & $7 \cdot 9881(13)$ & $11 \cdot 2967(17)$ & $17 \cdot 4649(18)$ \\
$c(\AA)$ & $21 \cdot 9223(37)$ & $16 \cdot 3814(24)$ & $11 \cdot 6597(13)$ \\
$\alpha\left(^{\circ}\right)$ & $90 \cdot 00$ & $90 \cdot 00$ & $90 \cdot 00$ \\
$\beta\left(^{\circ}\right)$ & $90 \cdot 00$ & $92 \cdot 636(3)$ & $92 \cdot 432(2)$ \\
$\gamma\left({ }^{\circ}\right)$ & $90 \cdot 00$ & $90 \cdot 00$ & $90 \cdot 00$ \\
$V\left(\AA^{3}\right)$ & $1183 \cdot 06(3)$ & $1471 \cdot 49(4)$ & $1510 \cdot 08(3)$ \\
$D_{\text {calc }}\left(\mathrm{mg} \mathrm{m}^{-3}\right)$ & $1 \cdot 23$ & $1 \cdot 25$ & $1 \cdot 43$ \\
$Z$ & 4 & 4 & 4 \\
$\mu\left(\mathrm{mm}^{-1}\right)$ & $0 \cdot 243$ & $0 \cdot 210$ & $2 \cdot 478$ \\
Reflections collected/unique & $9231 / 2325$ & $12623 / 3478$ & $4438 / 4150$ \\
Parameters & 137 & 181 & 361 \\
$R_{\text {int }}$ & $0 \cdot 025$ & $0 \cdot 042$ & $0 \cdot 014$ \\
$R^{\mathrm{a}}$ & $0 \cdot 043$ & $0 \cdot 061$ & $0 \cdot 041$ \\
$R_{\mathrm{w}}^{\mathrm{b}}$ & $0 \cdot 097$ & $0 \cdot 162$ & $0 \cdot 087$ \\
Goodness-of-fit on $F^{2}$ & $1 \cdot 071$ & $1 \cdot 112$ & $0 \cdot 987$ \\
$\Delta \rho_{\text {min }}$ and $\Delta \rho_{\text {max }}\left(\mathrm{e} . \AA^{-3}\right)$ & $-0 \cdot 121$ and $0 \cdot 262$ & $-0 \cdot 304$ and $0 \cdot 551$ & $-0 \cdot 345$ and $0 \cdot 411$ \\
\hline
\end{tabular}

nificant shortening of the $\mathrm{C}$ (ethylenic)- $\mathrm{N}$ bonds in the imidazole ring in the selone $\mathbf{1 0}$ point to a delocalized zwitterionic structure as shown for MSeI. When we compare the structure of the thione 9 with that of its selenium analogue 10, it appears that $\mathrm{C}_{-}$ Se bond in compound $\mathbf{1 0}$ is more polarized than the $\mathrm{C}-\mathrm{S}$ bond in compound 9 , indicating a weak $\mathrm{C}-\mathrm{Se}$ pi-overlap in the selenium compound.

\subsection{Inhibition of lactoperoxidase-catalysed oxidation}

The inhibition of peroxidase-catalysed oxidation reactions by thiourea compounds has been routinely used not only to determine the potency of clinically useful anti-thyroid drugs, but also to understand the mechanism by which the drugs exert their antithyroidal activity. Although the inhibition of thyroid peroxidase (TPO) and a related enzyme, lactoper- oxidase (LPO) by anti-thyroid agents has been studied extensively in recent years, the mechanism of the inhibition of heme-peroxidases or the inhibition of peroxidase-catalysed oxidation and iodination reactions is still not clear. Magnusson et al suggested that the inhibition of TPO or LPO by the thiourea drugs may occur through competition with hydrogen peroxide for a common form of oxidized iodine. ${ }^{13}$ Davidson et al proposed that anti-thyroid drugs block the iodination in vivo by reducing the oxidized iodide generated by the TPO, thus diverting it from the natural substrate tyrosyl residues. ${ }^{14}$ In contrast, Engler et al suggested that MMI and PTU exert their activity by reacting with the oxidized TPO heme group and thus inactivating the enzyme. ${ }^{15}$ It is also possible that the thiourea drugs are oxidized by the $\mathrm{TPO} / \mathrm{H}_{2} \mathrm{O}_{2}$ system and the drugs in their oxidized forms may bind to the heme group of the enzyme. Taurog and Dorris, on the other hand, suggested that 
the inhibition of iodination by compounds such as PTU involves a competition reaction between the drugs and tyrosine residues of thyroglobulin $(\mathrm{Tg})$ for oxidized iodine. ${ }^{14,16}$

In the present study, we have carried out the enzyme inhibition experiments with lactoperoxidase (LPO, figure 6) since it is readily available in purified form. ${ }^{17}$ Furthermore, LPO has been shown to behave similarly to TPO with respect to iodination of thyroglobulin, the natural substrate, and other iodide acceptors. ${ }^{18}$ Edelhock et al have reported the inactivation of LPO by thiourea-based drugs using LPO-N-acetyltyrosylamide assay. ${ }^{19}$ We have employed 2,2'-azio-bis 3-ethyl-benthiazoline-6-sulphonic acid (ABTS) and $\mathrm{H}_{2} \mathrm{O}_{2}$ as substrates to determine the half-maximal inhibitory concentration $\left(\mathrm{IC}_{50}\right)$ of test compounds. ${ }^{6,20,21}$ The LPO activities at different concentration of MMI and MSeI are summarized in figure 7 and the corresponding $\mathrm{IC}_{50}$ values are given in table 2 , respectively.

To obtain reliable $\mathrm{IC}_{50}$ values for compound $\mathbf{2}$ and to make a direct comparison with the sulfur analogue,

(a)

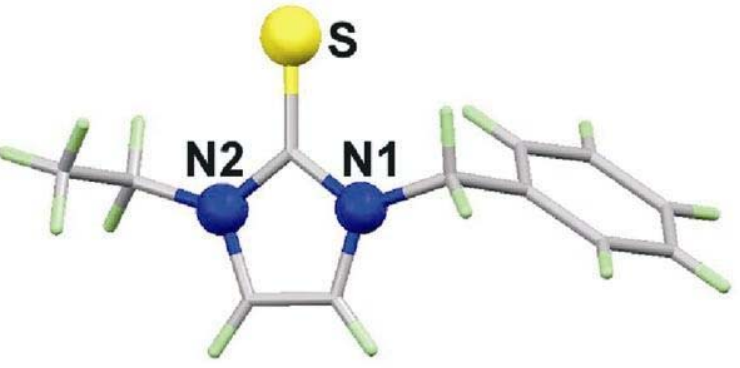

(b)

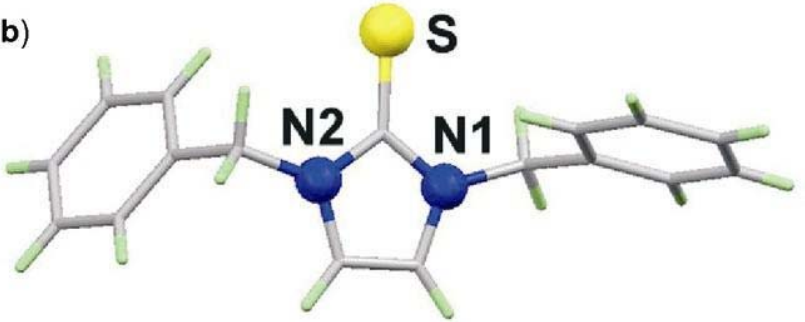

(c)

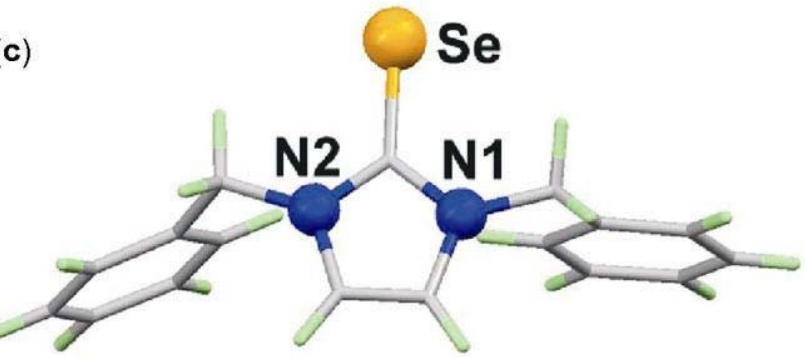

Figure 5. X-ray crystal structures of compounds 7 (a), 9 (b) and 10 (c). it is important to carry out the inhibition experiments with the completely reduced species. We have observed that the selenium compound obtained directly from the reaction does not give any reproducible results because it contains a mixture of MSeI and the corresponding diselenide. Therefore, we carried out the experiment with the reduced species (2), which was obtained by reducing the diselenide with $\mathrm{NaBH}_{4}$ in an aqueous solution and extracted in dichloromethane. However, compound 2 generated by this method is reasonably stable to obtain reliable $\mathrm{IC}_{50}$ values.

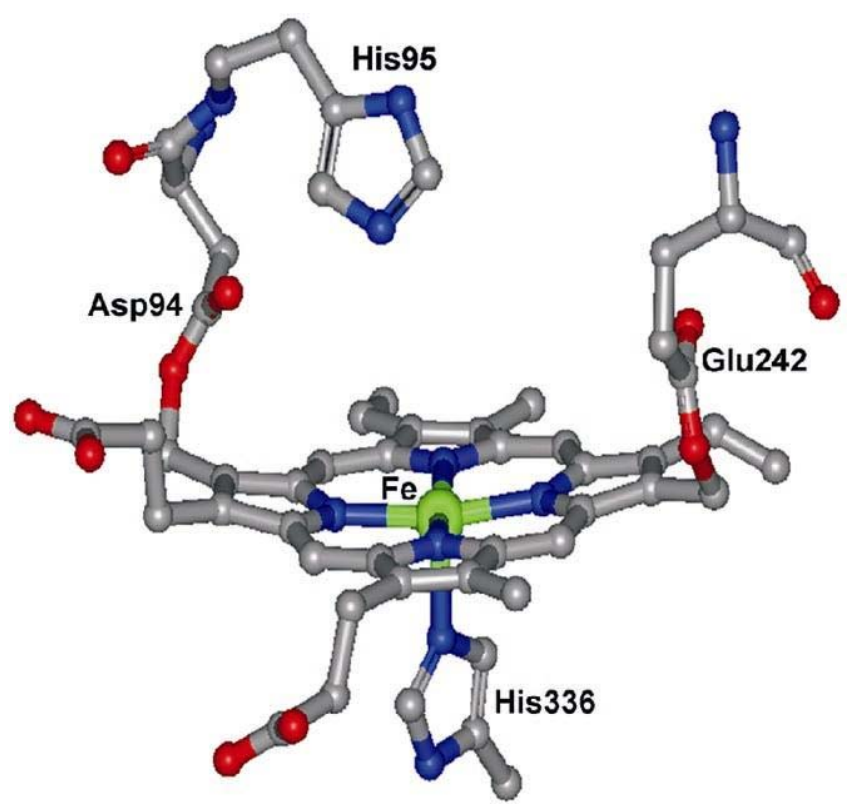

Figure 6. The active site structure of lactoperoxidase (PDB Code: $2 \mathrm{GJ} 1)^{17}$

Table 2. Inhibition of LPO activity by compounds 1-3, 5, and 7-10.

\begin{tabular}{lcc}
\hline No. & Compound & $\mathrm{IC}_{50}(\mu \mathrm{M})^{\mathrm{a}}$ \\
\hline 1 & MMI (1) & $7 \cdot 8$ \\
2 & MSeI (2) & $16 \cdot 4$ \\
3 & PTU (3) & 45.0 \\
4 & MTU (5) & $47 \cdot 8$ \\
5 & 7 & Inactive $^{\mathrm{b}}$ \\
6 & $\mathbf{8}$ & $12 \cdot 3$ \\
7 & $\mathbf{9}$ & Inactive $^{\mathrm{b}}$ \\
8 & $\mathbf{1 0}$ & $9 \cdot 6$ \\
\hline
\end{tabular}

${ }^{\mathrm{a}}$ Concentration of the compound causing $50 \%$ inhibition. ${ }^{\mathrm{b}}$ The compounds were inactive up to $100 \mu \mathrm{M}$ and some solubility problems in the test buffer were observed above this concentration 

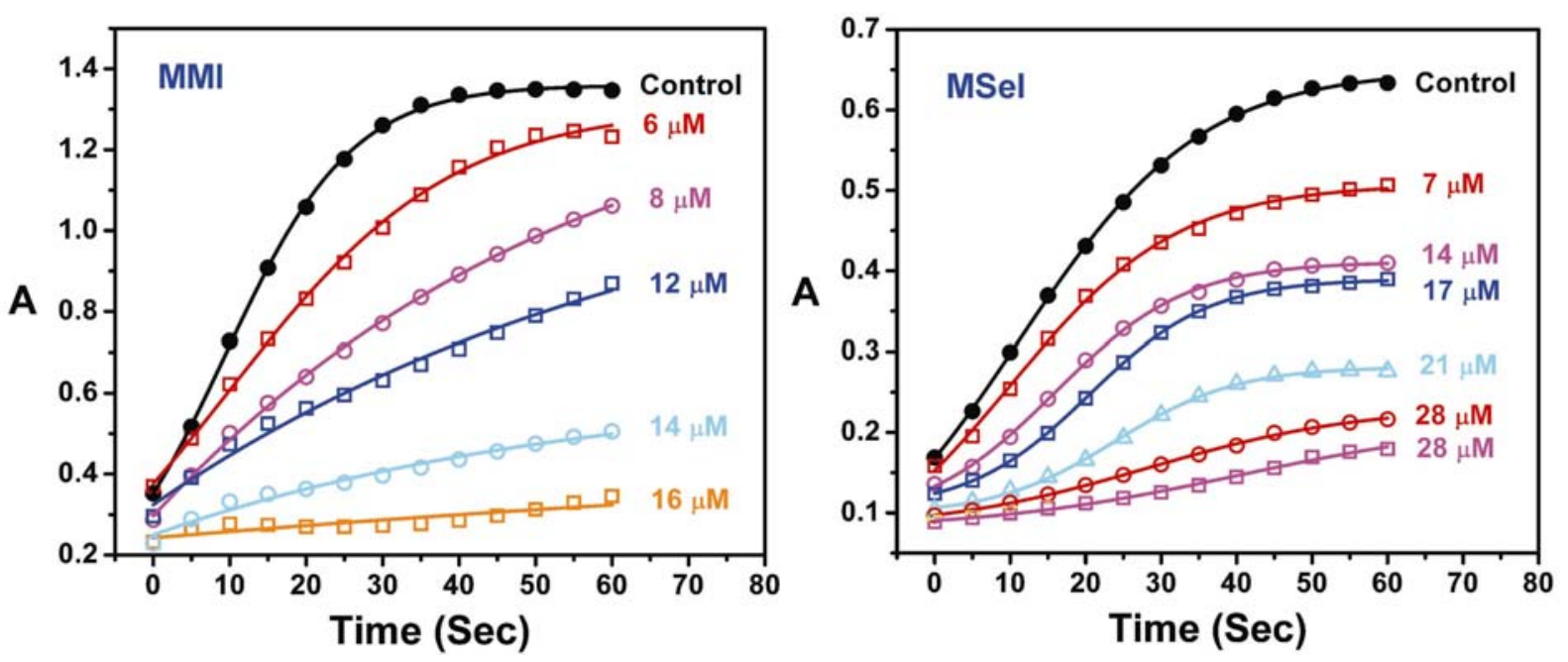

Figure 7. Inhibition of LPO-catalysed oxidation of ABTS by MMI and MSeI at pH 7 and $30^{\circ} \mathrm{C}$. The reaction mixture contained $0.5 \mu \mathrm{g} / \mathrm{ml}$ LPO, $1.4 \mathrm{mM}$ ABTS, $0.067 \mathrm{M}$ phosphate buffer (pH 7) and $28.67 \mu \mathrm{M} \mathrm{H}_{2} \mathrm{O}_{2}$. The reaction was initiated by addition of $\mathrm{H}_{2} \mathrm{O}_{2}$. The initial formation of ABTS radical cation was monitored by an UV-vis spectrophotometer at $411 \mathrm{~nm}$.

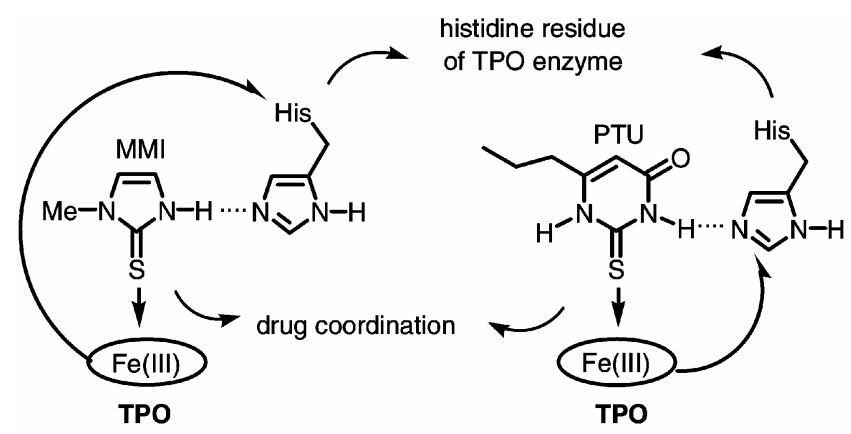

Figure 8. A hypothetical model for the coordination of thiourea drugs to the Fe-center of TPO.

Similarly to the inhibition of LPO by MMI, the LPO activity decreases with an increase in the concentration of MSeI (figure 7). As expected, MMI exhibited high inhibitory activity towards LPO with an $\mathrm{IC}_{50}$ value of $7.8 \mu \mathrm{M}$, which is much lower than that observed with PTU and MTU. The selenium analogue (2) also inhibited $\mathrm{LPO}$, and the $\mathrm{IC}_{50}$ value was found to be almost three times lower than that of PTU and MTU. The higher activity of MMI as compared with PTU and MTU is in agreement with the previous studies on the inhibition of TPO. ${ }^{15 a, 22}$ Since the activation of the iron center in TPO must proceed through an interaction of $\mathrm{Fe}(\mathrm{III})$ with $\mathrm{H}_{2} \mathrm{O}_{2}$, the inhibition of TPO may occur through a competitive coordination of the drug to iron, assisted by hydrogen bonding with a histidine residue of the TPO enzyme (figure 8) ${ }^{23}$ Under these conditions, MMI

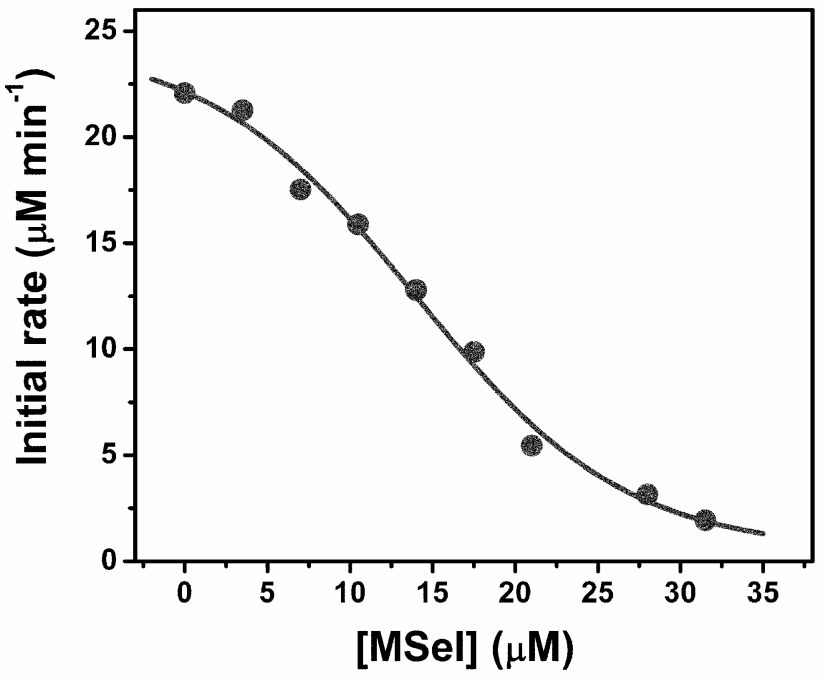

Figure 9. Plot of initial rates $\left(v_{\mathrm{o}}\right)$ for the LPO-catalysed oxidation of ABTS vs concentration of MSeI (2). The reaction mixture contained $0.5 \mu \mathrm{g} / \mathrm{ml}$ LPO, $1.4 \mathrm{mM}$ ABTS, $0.067 \mathrm{M}$ phosphate buffer (pH 7) and $28.67 \mu \mathrm{M}$ $\mathrm{H}_{2} \mathrm{O}_{2}$. The reaction was initiated with $\mathrm{H}_{2} \mathrm{O}_{2}$. The formation of ABTS radical cation was monitored at $411 \mathrm{~nm}$.

might compete more successfully than PTU with $\mathrm{H}_{2} \mathrm{O}_{2}$, because the hydrogen-bond (hard) basicity $\mathrm{pk}_{\mathrm{HB}}$ value of MMI $(2 \cdot 11)$ is much higher than that of PTU $(\sim 1.32))^{7 \mathrm{~g}}$ Similar to PTU, the methyl derivative 6 (MTU) is also expected to be a weak inhibitor of TPO. On the other hand, the nucleophilicity of the selenium moiety in compound 2 that exists predominantly in its zwitterionic form is expected 

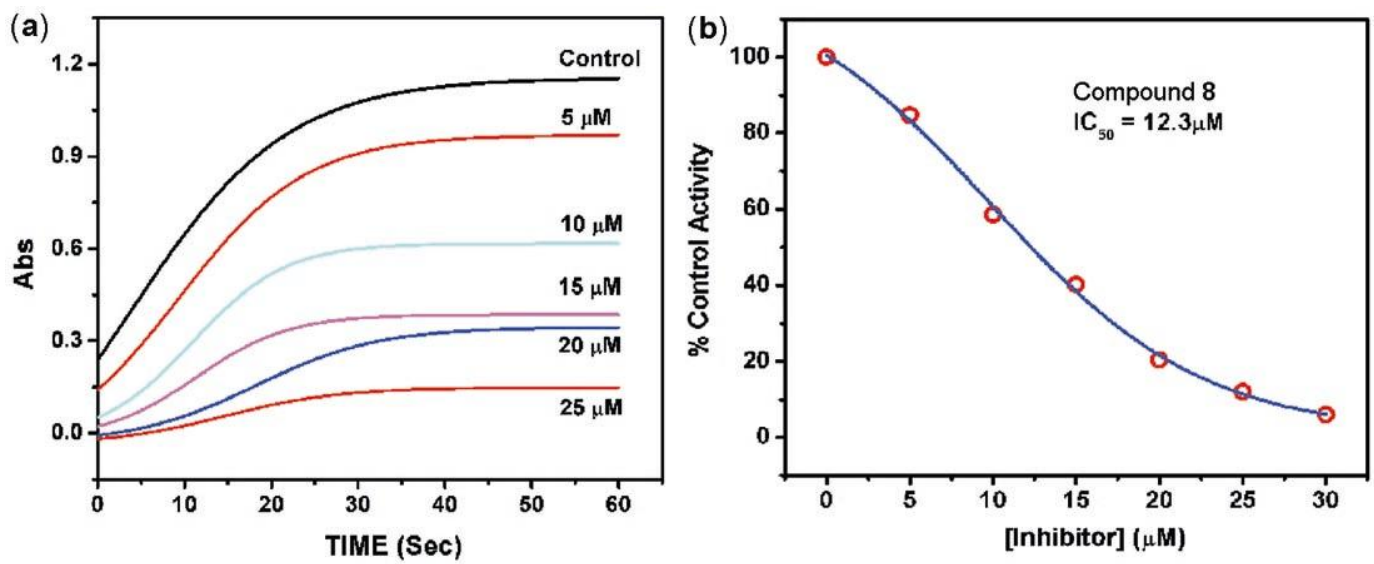

Figure 10. (a) Effect of compound 8 on the LPO-catalysed oxidation of ABTS. (b) Inhibition plots obtained by plotting the \% control activity against the concentrations of compound $\mathbf{8}$.

to be much higher than that of the sulfur analogue. However, the lower activity of MSeI as compared with MMI indicates that the selenium analogue of MMI may inhibit LPO by a different mechanism.

As expected, the plot of initial rates $\left(v_{0}\right)$ vs concentration of MSeI shows that the rate of the reaction decreases with increasing concentration of MSeI (figure 9). In all these cases, the LPO activity could be recovered by increasing the hydrogen peroxide concentration. These experimental observations support the conclusions made by Taurog et al that MSeI, unlike MMI, cannot act as an irreversible inhibitor of TPO. These observations also support the in vivo experiments, which showed that MMI is at least 50 times more potent than MSeI as an inhibitor of organic iodine formation in the thyroid. ${ }^{5}$ Crucially, the treatment of $\mathbf{2}$ with the selenolate specific reagent, iodoacetic acid, abolished the inhibitory potency of $\mathbf{2}$, confirming that the oxidation of the selenolate group by $\mathrm{H}_{2} \mathrm{O}_{2}$ is responsible for the inhibition. In contrast, the sulfur analogue MMI was found to be less sensitive to the iodoacetic acid treatment, and this also confirms that the thiol (or thiolate) form of MMI is not only less predominant in solution but also less reactive as compared with the thione form. The decrease in the inhibitory activity of $\mathbf{2}$ upon iodoacetic acid treatment can be ascribed to the formation of a protected selenide as a dead-end product.

In contrast to MMI, the thiones $\mathbf{7}$ and 9, which do not have any free $\mathrm{N}-\mathrm{H}$ group do not inhibit the LPO-catalysed oxidation. Surprisingly, the replacement of sulfur atoms in compounds 7 and 9 with sele- nium (i.e. compounds 8 and 10) led to almost a complete inhibition of LPO activity with $\mathrm{IC}_{50}$ values of $12.3 \mu \mathrm{M}$ and $9.6 \mu \mathrm{M}$, respectively, which are lower than that of MSeI $(16.4 \mu \mathrm{M})$. Also, these two selenium compounds are much more active than the 2-thiouracil derivatives. The effect of 8 on the LPOcatalysed oxidation of ABTS is summarized in figure $10 \mathrm{a}$ and the inhibition plot for $\mathbf{8}$ is shown in figure 10b. Although compounds 8 and $\mathbf{1 0}$ lack the essential $\mathrm{N}-\mathrm{H}$ group, the higher inhibitory activity of these compounds as compared with their sulfur analogues can be ascribed to the existence of $\mathbf{8}$ and 10 in zwitterionic structures where the selenium moiety acts as a selenolate rather than a selone. Similarly to MSeI (2), the negatively charged selenium moiety may scavenge the $\mathrm{H}_{2} \mathrm{O}_{2}$ substrate effectively present in the model system (ABTS assay) or this compound may interfere with the oxidized LPO species, leading to a reversible inactivation.

\section{Conclusion}

In this paper, we have described the keto-enol type tautomerism in anti-thyroid drugs and their selenium analogues. The present study supports our previous observations that the anti-thyroid agent methimazole (MMI) exists predominantly in its thione form, whereas its selenium analogue exists in a zwitterionic form with a large negative charge on selenium. We have studied the importance of thione/thiol and selone/selenol tautomerism on the inhibition of peroxidase-catalysed reactions by using N,N-disubstituted thiones and selones. These studies reveal that the presence of a free $\mathrm{N}-\mathrm{H}$ moiety in the sulfur-based 
compounds is essential for an efficient inhibition. In contrast to the thiones, the $\mathrm{N}, \mathrm{N}$-disubsituted selones were found to be efficient inhibitors of LPO-catalysed oxidation, indicating that the free N-H moiety is not required for the inhibition.

\section{Acknowledgement}

This study was supported by the Department of Science and Technology (DST), New Delhi. G M acknowledges the DST for Ramanna Fellowship. P N J and G R thank the DST and Council of Scientific and Industrial Research (CSIR), New Delhi, respectively, for research fellowships.

\section{References}

1. (a) Dunford H B 1999 Heme peroxidases (New York: Wiley-VCH); (b) Furtmüller P G, Zederbauer M, Jantschko W, Helm J, Bogner M, Jakopitsch C and Obinger C 2006 Arch. Biochem. Biophys. 445199

2. (a) Carayon P and Ruf J 1990. Thyroperoxidase and thyroid autoimmunity (London: John Libbey); (b) Taurog A Thyroid hormone synthesis. 1991 In Werner's the thyroid (eds) L E Braverman and R D Utiger p. 51; (c) Taurog A, Dorris M L and Doerge D R 1994 Arch. Biochem. Biophys. 315 82; (d) Doerge D R, Taurog A and Dorris M L 1994 Arch. Biochem. Biophys. 315 90; (e) Doerge D R 1995 Xenobiotica 25 761; (f) Taurog A, Dorris M L and Doerge D R 1996 Arch. Biochem. Biophys. 330 24; (g) Ruf J and Carayon P 2006 Arch. Biochem. Biophys. 445269

3. (a) Behne D, Kyriakopoulos A, Meinhold H and Köhrle J $1990 \mathrm{~J}$. Biochem. Biophys. Res. Commun. 173 1143; (b) Berry M J, Banu L and Larsen P R 1991 Nature (London) 349 438; (c) Berry M J, Kieffer J D, Harney J W and Larsen P R $1991 \mathrm{~J}$. Biol. Chem. 266 14155; (d) Köhrle J 1994 Exp. Clin. Endocrinol. 102 63; (e) Larsen P R and Berry M J 1995 Ann. Rev. Nutr. 15 323; (f) Bianco A C, Salvatore D, Gereben B, Berry M J and Larsen P R 2002 Endocrine Rev. 23 38; (g). Köhrle J 2002 Meth. Enzymol. 347125

4. (a) Engler H, Taurog A, Luthy $\mathrm{C}$ and Dorris $\mathrm{M} \mathrm{L}$ 1983 Endocrinology 112 86; (b) Taurog A 1976 Endocrinology 981031

5. (a) Visser T J, Kaptein E and Aboul-Enein H Y 1992 Biochem. Biophys. Res. Commun. 189 1362; (b) Aboul-Enein H Y, Awad A A and Al-Andis N M 1993 J. Enzyme Inhib. 7 147; (c) Taurog A, Dorris M L, Guziec L J and Guziec Jr F S 1994 Biochem. Pharmacol. 48 1447; (d) Guziec L J and Guziec Jr F S 1994 J. Org. Chem. 59 4691; (e) Taurog A, Dorris $\mathrm{M} \mathrm{L}, \mathrm{Hu}$ W-X and Guziec Jr F S 1995 Biochem. Pharmacol. 49 701; (f) Antoniadis C D, Hadjikakou S K, Hadjiliadis N, Papakyriakou, A Baril M and Butler I S 2006 Chem. Eur. J. 126888
6. (a) Roy G, Nethaji M and Mugesh G $2004 \mathrm{~J}$. Am. Chem. Soc. 126 2712; (b) Roy G and Mugesh G 2005 J. Am. Chem. Soc. 127 15207; (c) Roy G; Nethaji M and Mugesh G 2006 Inorg. Chem. Commun. 9 571; (d) Roy G; Nethaji M and Mugesh G 2006 Org. Biomol. Chem. 4 2883; (e) Roy G and Mugesh G 2006 Bioinorg. Chem. Appl. 2006 1; (f) Roy G and Mugesh G 2006 J. Chem. Sci. 118 619; (g) Roy G, Das D and Mugesh G 2007 Inorg. Chim. Acta 360303

7. (a) Murai $\mathrm{T}$ and Kato S 2000 Selenocarbonyls In Topics in current chemistry (ed.) T Wirth (Berlin: Springer-Verlag) 208 177; (b) Kjellin G, Sandström J 1969 Acta Chem. Scand. 23 2888; (c) Fauré R, Vincent E J, Assef G, Kister J and Metzger J 1977 Org. Magn. Reson. 9 688; (d) Bojarska-Olejnik E, Stefaniak L, Witanowski M, Hamdi B T, Webb G A 1985 Magn. Reson. Chem. 23 166; (e) Balestrero R S, Forkey D M and Russell J G 1986 Magn. Reson. Chem. 24 651; (f) Antoniadis C D, Corban G J, Hadjikakou S K, Hadjiliadis N, Kubicki M, Warner S and Butler I S 2003 Eur. J. Inorg. Chem. 8 1635; (g) Laurence C, El Ghomari M J, Le Questel J-Y, Berthelot M and Mokhlisse R 1998 J. Chem. Soc., Perkin Trans. 21545

8. Landry V K, Minoura M, Pang K, Buccella D, Kelly B V and Parkin G $2006 \mathrm{~J}$. Am. Chem. Soc. 128 12490

9. Visser T J, Van Overmeeren E, Fekkes D, Docter R and Hennemann G 1979 FEBS Lett. 103314

10. Ansell G B, Forkey D M and Moore D W 1970 Chem. Comm. 56

11. Tomlin D W, Campbell D P, Fleitz P A and Adams W W 1997 Acta Cryst. C53 1153

12. (a) Pauling L 1960 The nature of the chemical bond, (Ithaca, New York: Cornell University Press), 3rd edn; (b) Krebs B and Koenig P F 1969 Acta Cryst. B25 1022

13. (a) Magnusson R P, Taurog A and Dorris M L 1984 J. Biol. Chem. 259 13783; (b) Magnusson R P, Taurog A and Dorris M L 1984 J. Biol. Chem. 259 197

14. Davidson B, Soodak M, Neary J T, Strout H V, Kieffer J D, Mover H and Maloof F 1987 Endocrinology 103871

15. (a) Engler H, Taurog A, Luthy $\mathrm{C}$ and Dorris $\mathrm{M} \mathrm{L}$ 1983 Endocrinology 112 86; (b) Engler H, Taurog A and Nakashima T 1982 Biochem. Pharmacol. 31 3801; (c) Shiroozu A, Taurog A, Engler H and Dorris M L 1983 Endocrinology 113362

16. Taurog A, Dorris M L and Guziec Jr F S 1989 Endocrinology 124 30, and references therein

17. Singh A K, Singh N, Sharman S, Bhushan A and Singh T P (unpublished results)

18. Taurog A, Dorris M L and Lamas L 1974 Endocrinology 941286

19. (a) Edelhoch $\mathrm{H}$, Irace $\mathrm{G}$, Johnson M L, Michot J L and Nunez J 1979 J. Biol. Chem. 254 11822; (b) Michot J L, Nunez J, Johnson M L, Irace G and Edelhoch H 1979 J. Biol. Chem. 254 2205; (c) Ohtaki S, Nakagawa H, Nakamura M and Yamazaki I $1982 \mathrm{~J}$. Biol. Chem. 257761 
20. Childs R E and Bardsley W G 1975 Biochem. J. 145 93

21. (a) Buxeraud J, Absil A C, Claude J, Raby C, Catanzano G and Beck C 1985 Eur. J. Med. Chem. 20 43; (b) Raby C, Lagorce J F, Jambut-Absil A C, Buxeraud J and Catanzano G 1990 Endocrinology 1261683

22. Taurog A 1976 Endocrinology 981031

23. (a) Although there is no definite evidence for the coordination of the thione moiety of the anti-thyroid drugs to the iron center, this model is given based on the fact that iron-sulfur coordination is very common in metalloenzymes and hydrogen bonding of heme ligands with a distal histidine appears to be common in peroxidases (For details: see Ref. 7g); (b) Bassosi R, Niccolai N and Rossi C 1978 Biophys. Chem. 861

24. Altomare A, Cascarano G, Giacovazzo C and Gualardi A 1993 J. Appl. Cryst. 26343

25. Sheldrick G M, SHELX-97 1990 Acta Crystallogr. A46 467

26. Sheldrick G M, SHELX-97 1997 Program for the Refinement of Crystal Structures, University of Göttingen, Göttingen, Germany 